\title{
PERCEPTION OF BIOLOGICAL MOTION IN CENTRAL AND PERIPHERAL VISUAL FIELDS
}

\author{
Ilze Laicāne ${ }^{1, \#}$, Jurǵis Šḳilters ${ }^{2}$, Vsevolod Lyakhovetskii ${ }^{3}$, Elīna Zimaša ${ }^{1}$, \\ and Gunta Krūmiṇa \\ ${ }^{1}$ Department of Optometry and Vision Science, Faculty of Physics and Mathematics, University of Latvia, \\ 1 Jelgavas Str., Riga, LV-1004, LATVIA \\ ${ }^{2}$ Laboratory for Perceptual and Cognitive Systems, Faculty of Computing, University of Latvia, LATVIA \\ ${ }^{3}$ Pavlov Institute of Physiology, Russian Academy of Sciences, 199034 Makarova emb., 6, Saint-Petersburg, RUSSIAN FEDERATION \\ \# Corresponding author, e-mail ilze.laicane@lu.Iv
}

Communicated by Ivars Lācis

\begin{abstract}
Studies analysing biological motion perception based on reduced number of dots have demonstrated that biological motion can be perceived even when only the lower part of the body is visible or when the number of dots representing the object is reduced. What is the minimal amount of information that enables biological motion to be distinguished from its scrambled version? The results of the current experiment demonstrate that biological motion can be distinguished from its scrambled version when the object is formed of approximately $5(4.7 \pm 0.1)$ dots. Additionally, we also investigated whether the threshold value for biological motion perception differs in central and peripheral visual fields. By using stimulus magnification, we demonstrate that the number of dots sufficient for biological motion perception is similar in the central visual field and near periphery. Hence, stimulus magnification can compensate for reduced task performance in the peripheral visual field. The current results suggest that reduced performance of biological motion perception in the peripheral visual field (as demonstrated in other studies) is due to difficulties with the global perception of biological motion.
\end{abstract}

Key words: biological motion, eccentricity, peripheral vision, stimulus magnification.

\section{INTRODUCTION}

Motion perception and analysis of the surrounding environment play a vital role in helping us to act and interact appropriately in a dynamic world. These abilities allow us to predict threatening situations, can give important information about the behaviour of other creatures, as well as provide significant information for social interaction (Barrett et. al., 2005). Motion perception can contribute to the perception of the three-dimensional shape of an object (Wallach and O'Connell, 1953; Sperling et al., 1989), provide information about motion parallax and contribute to perceptual organisation when the visual information is structured by grouping principles such as the Gestalt principle of common fate (Palmer, 1999).

One of the most intriguing categories of motion analysis is the movement of a living organism. Swedish psychophysicist Gunnar Johansson (1973) was the first who noticed that it was sufficient to demonstrate only the movement of the major joints in order to perceive motion of the whole body. By adding patches of retroreflective material to the main joints of a human, recording the activities and turning con- trast of the video material to maximum, he demonstrated that observers are capable of identifying the nature of movement immediately even in the case when no additional information about the shape of the body is given. Furthermore, it is possible to not only perceive motion from a limited amount of visual information, but also recognise a familiar person, discriminate the direction of the movement as well as different characteristics of the object including gender, mood and emotions (Cutting and Kozlowski, 1977; Kozlowski and Cutting, 1977; Clarke et al., 2005; McKay et al., 2006; Blake and Schiffrar, 2007; Atkinson, 2009; Nackaerts et al., 2012).

Johansson (1973) also demonstrated that a reduced number of dots can still create the perception of biological motion even when only the points corresponding to the legs and hips are visible. As demonstrated by Mather et al. (1992) observers are even capable of detecting motion direction when an object is formed of a reduced number of points, however these points must include wrists and ankles. Biological motion can also be perceived when the joints for demonstration are chosen randomly and during one gait cycle all of them are presented, but in different time periods, 
which demonstrates the sensitivity of human visual system to other human motion (Neri et al., 1998; Beintema and Lappe, 2002).

The perception of biological motion is a complex process that involves the analysis of low-level features, such as speed and motion trajectory of every single dot (local information), as well as high-level features that analyse the whole body as a unity and assigns a certain meaning to it (global information analysis) (see discussion by Thornthon et al., 2002). However, the extent to which the local and global information analysis contribute to perception of biological motion is not entirely clear. According to studies that analysed the perception of a biological object in conditions of visual motion noise, it is not possible to recognise a biological object by only analysing the low-level motion trajectories of isolated dots. When demonstrating a pointlight-walker embedded in motion noise, consisting of dots with the same physical properties (including dot size, motion trajectories, etc.) as the dots forming the biological object and thus preserving the local motion information, the observer is still capable of distinguishing between the object of biological motion and the noise, by using the information about the whole structure of the object (Cutting et al., 1988; Bertenhal and Pinto, 1994; Giese and Lappe, 2002; Ikeda et al., 2005; Freire et al., 2006; Schouten et al., 2013).

On the other hand, although sufficient for biological motion perception, global motion analysis alone cannot give full information about all the characteristics of the point-light walker. The role of local informational analysis in biological motion perception has been demonstrated in walking direction and gender discrimination tasks: information about motion direction is carried by feet motion (Troje and Westhoff, 2006; Wang et al., 2014) and the information about gender is carried by the local information of hips and shoulders (Kozlowski and Cutting, 1977; Barclay et al., 1978; Mather and Murdoch, 1994).

The current study addresses the perception of biological motion in the central and peripheral visual fields, analysing what processes determine the accurate perception of a point-light walker. When analysing the perceptual processes in the periphery, it is needed to take into account the physiological fact that with increasing eccentricity, the sensitivity to detailed information is decreasing because of differences in retinal cone cell density, the proportion of lateral geniculate nucleus cells per one ganglion cell, as well as the number of striate cells for every projection from fovea (Duncan and Boynton, 2003). However, the perception of some processes can be equalised in central and peripheral visual fields, only by using stimulus magnification, i.e. improving task performance in the peripheral visual field and equalising it to performance in central visual field, by only increasing the stimulus size.

Stimulus magnification has been demonstrated to be sufficient for compensating the reduced performance in visual field periphery in the case of visual acuity (Boyton and Duncan, 2002), orientation discrimination (Sally and Gurn- sey 2003), letter recognition (Higgins et al., 1996), contrast sensitivity (Rovamo et al., 1978), and even perceptual grouping (Tannazzo et al., 2014). However, at other times stimulus magnification alone is not sufficient for compensating the reduced performance, e.g., in the case of face recognition (Makela et al., 2001) and reading speed (Chung et al., 1998), indicating that the central visual field is more specialised in analysing more specific and detailed information of our environment.

It might seem that in the case of motion analysis, the peripheral visual field should be more sensitive and specialised in analysing different motion stimuli, since the $\mathrm{M}$ ganglion cells forming the magnocellular pathway are more distributed in the peripheral retina than in fovea (Meissirel et al., 1997). However, all of the previously mentioned factors (cortical magnification, retinal cell density, etc.) that influence object perception in the central visual field can decrease performance in the periphery.

In a comprehensive review on peripheral motion perception (Finlay, 1982) it is argued that the central visual field is in general more precise regarding motion analysis, e.g. when detecting a just a noticeable object displacement, as well as the differences between velocities or analysing the lowest perceptible velocity thresholds. McKee and Nakayama (1984) demonstrated similar results and concluded that even in the case of stimulus magnification the threshold value for differential motion detection did not reach the same level in the peripheral visual field as it did in the central visual field. However, there are cases when the opposite can also be observed, e.g., the peripheral visual field is more efficient in detecting movement of stimuli with higher velocities (Finlay, 1982; Lappin et al., 2009). Hence, it seems that there are differences between motion perception in central and peripheral visual fields. Furthermore, the central visual field is more specialised for perception of accurate, slow movements whereas the peripheral visual field shows better results when an object is moving with higher velocities (Wurbs et al., 2013).

It is clear that, similarly to simple motion, the analysis of biological motion in the peripheral visual field is affected by cortical magnification, size of the receptive fields and other factors determining functional differences between perceptual processes in central and peripheral visual fields. Analogously to the previously mentioned studies that analysed visual acuity, face perception, etc., studies analysing the sensitivity to biological motion also use stimulus magnification (Ikeda et al., 2005; Gurnsey et al., 2008; 2010). However, the results of these studies are quite ambiguous.

Ikeda et al. (2005) described the eccentric perception of biological motion as "unscalably poor", showing that when the stimulus ass embedded in motion noise the discrimination of a point light walker from its scrambled version was more effective in the central visual field and stimulus magnification did not compensate for reduced performance in the peripheral visual field. On the other hand, Gurnsey et al. (2008) come to completely opposite results by analysing the 
facing direction of a biological object and demonstrated that increase in stimulus size equalised the performance in both central and peripheral visual fields. Although both of these studies used a similar experimental setup, their results and main conclusions seem to be entirely opposite. Gurnsey et al. (2008) argued that the differences might have been related to the fact that discriminating an object from motion noise (used by Ikeda et al., 2005) requires global perception of the whole body, and determining facing direction (without additional motion noise) is more related to local analysis of motion trajectories of the feet. Hence, the functional differences between these results were not due to differences in perception of biological motion but rather due to the reduced performance in element grouping or figureground discrimination in the peripheral visual field.

The current study was designed to determine the number of dots sufficient for biological object recognition, as well as assess processing of biological motion in the peripheral visual field without any motion noise. By randomly reducing the number of dots that represented a biological object we investigated whether the performance in discriminating the biological object from its scrambled version could be compensated by stimulus magnification.

\section{MATERIALS AND METHODS}

Eight participants (one male, seven female, aged 21-25 years) participated in the study. All subjects had normal or corrected-to-normal vision and reported no eye pathologies that they were aware of.

The study was approved by the Ethics Committee of Experimental and Clinical Medical Institute, University of Latvia. All participants gave their written consent for participation in the experiment.

Stimuli. The stimuli were generated from the action database developed by Vanrie and Verfaillie (2004). The database contains spatial coordinates of point-light walkers for generation of customised biological motion stimuli. The participants were presented with either a point light walker (Fig. 1A) heading in one of five different directions ( 0 degrees, 90 degrees left or right, 45 degrees left or right) or with a scrambled version of biological motion (Fig. 1B). The points of the scrambled version were the same size as the points forming point light walker and were moving along the same trajectory and with the same speed as randomly chosen points of one of the five point-light walkers. However, in the case of the scrambled version the positions of all points were changed and the points were randomly distributed within an area of the same size as used for biological motion demonstration. The starting phase of every point in the scrambled version was randomised and point movement was inverted (taken from the inverted (upsidedown) versions of point light walkers facing in either of five directions of the walkers). Upside-down versions were chosen in order to avoid situations when randomly selected dots in the scrambled version could accidentally form an
A

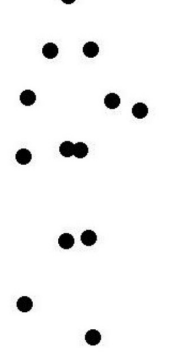

B

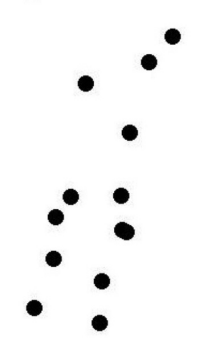

Fig. 1. (A) Point-light walker and (B) a scrambled version of biological motion.

object similar to a point-light walker. All stimuli were expressed as moving red dots (luminance $45 \mathrm{~cd} / \mathrm{m}^{2}$ ) on a white background (luminance $193 \mathrm{~cd} / \mathrm{m}^{2}$ ).

Procedure. The stimuli were presented on a computer screen (iiyama ProLite T2253MTS, 22", $1920 \times 1080$ pixels, Refresh rate $60 \mathrm{~Hz}$ ). The distance to the screen was 60 centimetres and the visual angle of the screen was 24 degrees vertically and 38 degrees horizontally. Participants viewed the screen binocularly. Every stimulus performed only one full gait cycle (30 frames demonstrated in $1 \mathrm{sec}-$ ond). After the presentation of the cycle, the stimulus disappeared and only a fixation cross remained, either at the centre of the screen or displaced to the left side. The biological object was always demonstrated in the centre of the screen and the participants were instructed to fix their gaze on the fixation cross during the experiment. Eccentricity was defined as the angular distance between the centre of fixation cross and the centre of a point light walker.

After presentation of a stimulus, participants were told to answer whether they had perceived a point-light walker and press "Y" when had seen it or "N" when did not see a point-light walker on the screen. If unsure, the participants were told to make a guess. Depending on response accuracy, every next point-light walker or scrambled version was generated with either more, fewer or the same number of points. The complete version of point-light walkers consisted of 13 points, and based on the responses, the number of points representing the object could be reduced down to 1 point. The choice of which dot was removed was random.

The stimulus presentation sequence was generated based on the adaptive staircase block up-down temporal interval forced-choice method BUDTIF (Campbell and Lacky, 1968; Levitt, 1971). The threshold probability for detecting a walker was $84.1 \%$ of the observers' psychometric function. Every block of trials consisted of four stimuli of the same level. In the case of four consecutive correct answers (100\% accuracy) the number of dots representing the point-light walker was reduced in the following block of stimuli. If at least one of four answers (0-75\% accuracy) was incorrect, the number of dots in the following block was increased. The stimulus level at the start of experiment was 13 points (complete version of a point-light walker). The initial step size in each run was 3 points. After the first 
three reversals, the step size was switched to 2 points, and after the following three reversals, the step size was switched to 1 point. A step size of 1 point was kept constant for the rest of experiment (six more reversals). The threshold value was calculated as the median number of dots in the last six reversals. All participants performed the task ten times.

The size of the stimulus was $1,2,4,8,16$ or 20 degrees and the object was presented in the central visual field and at three different eccentricities: 4, 8, and 15 degrees. Object size and chosen eccentricities were similar to parameters used in Ikeda et al. (2005) and Gurnsey et al. (2008). Point size was scaled proportionally to the object size. The size of one point for the largest stimulus (20 degrees) was 2 millimetres $(0.2$ degrees $)$, which corresponds to the smallest resolvable detail for visual acuity 0.08 . Since the average visual acuity at 15 degrees eccentricity is 0.15 (Kalloniatis and Luu, 2005), the chosen stimulus was large enough to be analysed in detail. The threshold value representing the number of dots sufficient for biological motion perception was determined for every participant with every stimulus size in every eccentricity.

\section{RESULTS}

The average results for all eight participants are demonstrated in Figure 2 (error bars represent the standard error of the mean value). The threshold value for biological motion perception ranged from 3 to 7 dots, with mean value $4.7 \pm$ 0.1 dots, demonstrating that 5 dots were sufficient for perception of biological motion of a point light walker. Task performance decreased in the case of eccentric demonstration, and increased with the size of stimuli. Regarding the smallest threshold values at each eccentricity, we observed that in the case of 4 degree eccentricity, all eight participants were able to reach the same threshold level as in the central visual field. At greater eccentricities the proportion of participants reaching the best performance decreased,

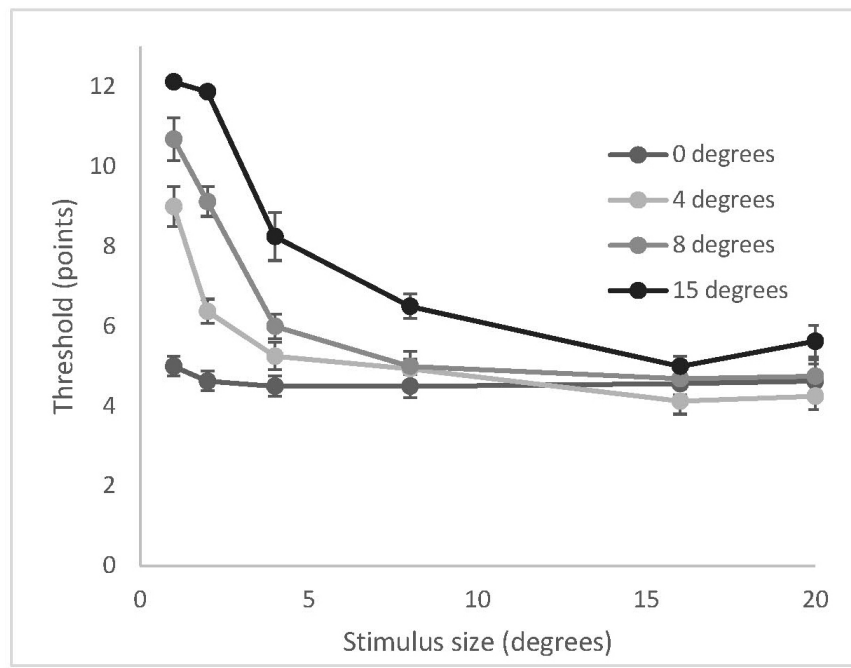

Fig. 2. Average threshold value for the eight participants when demonstrating objects with different size in four different eccentricities. Error bars represent standard error of the mean value. and at 8 and 15 degree eccentricities the same threshold value as for the central visual field was reached only by $63 \%$ and $50 \%$ of the participants. However, the difference between the best threshold values reached in the central visual field and at eccentricities did not exceed 1 point.

A two-way repeated measures ANOVA was conducted to evaluate the impact of stimulus size $(1,2,4,8,16$, and 20 degrees) and eccentricity (0, 4, 8, and 15 degrees) and the interaction between stimulus size and the eccentricity on the number of dots sufficient for biological motion perception. Since the Mauchly's Test of Sphericity indicated that the assumption of sphericity was violated for both the eccentricity $(\chi 2(5)=13.592, p=0.02, \varepsilon=0.438)$ and object size $\left(\chi^{2}(14)=73.780, p<0.001, \varepsilon=0.226\right)$, Geisser-Greenhouse adjusted $F$ ratios were used in further data analysis. The results demonstrated significant main effects for stimulus size $(\mathrm{F}(1.131 ; 7.916)=10.213, p=0.011)$ and eccentricity $(\mathrm{F}=(1.315 ; 9.208)=10.983, p=0.006)$. However, the interaction was not statistically significant $(\mathrm{F}(1.115 ; 7.807)$ $=2.338, p=0.166$ ).

To evaluate whether size scaling can compensate for reduced performance on the peripheral visual field, a one-way ANOVA test was performed separately for each stimulus size to test significant differences between the eccentricities. The significance levels for multiple comparisons were adjusted with the Bonferroni method (0.008). As expected, when using smaller stimulus sizes the performance on the peripheral visual field was impaired, shown by significant differences at various eccentricities: for stimulus sizes 1 degree $(\mathrm{F}(3.28)=54.6841, p<0.008), 2$ degrees $(\mathrm{F}(3.28)=$ 116.0684, $p<0.008), 4$ degrees $(\mathrm{F}(3.28)=14.3415, p<$ $0.008)$ and 8 degrees $(\mathrm{F}(3.28)=6.6314, p<0.008)$. At stimulus size was of 16 degrees, there was no significant difference between eccentricities $(\mathrm{F}(3.28)=0.9799, p=$ 0.42). At stimulus size 20 degrees, the performance slightly declined, but the difference was not significant $(\mathrm{F}(3.28)=$ $1.8841, p=0.16)$. The results clearly demonstrated that a sufficient object scaling can compensate for reduced performance on the peripheral visual field.

\section{DISCUSSION}

Johansson (1973) was the first to introduce the term "biological motion", by showing that it is sufficient to demonstrate only the motion of the major joints in order to spontaneously achieve a clear impression of a human being and the actions the person is performing. Furthermore, his results demonstrated that the recognition of biological motion is possible when only 5 points corresponding to the lower part of the body are demonstrated (hips, knees, and feet). Mather et al. (1992) demonstrated that biological motion direction can still be determined when the object is formed of 8 dots. However, performance significantly declined worse when dots corresponding to wrists and ankles were removed; in all other cases performance was close to the full object version. 
Beintema and Lappe (2002) also used an experimental setup with a reduced number of dots corresponding to major joints of the human body. Each frame consisted of 1, 2, 4, or 8 dots and the chosen limb or limbs for demonstration was kept constant for a limited number of frames (after which a different limb was demonstrated). They concluded that in the case when a larger number of sequentially demonstrated frames contained information about the motion of 1 or 2 limbs, the performance deteriorated and was near chance-level. Performance was nearly constant regardless of the number of frames, when the stimulus contained at least 4 points. However, since the 4 dots representing the object were sequentially switched to other limbs, the participants were still able to grasp the whole information about the object structure.

Although previous studies demonstrated that biological motion perception is possible even when a point-light walker is formed of a reduced number of dots and that local information analysis about feet motion plays a crucial role in direction discrimination tasks, there is still discussion regarding the minimal number of dots sufficient for biological motion detection. By randomly reducing the number of dots representing the point-light walker, we determined the minimal number of elements sufficient for biological motion perception. The results from eight participants demonstrated that the average threshold value for object recognition is almost $5(4.7 \pm 0.1)$ points. As suggested by Giese (2015), our neural system combines information from different informative cues and uses both local form and motion features to perceive a global configuration of a human body. It has been well established that perceptual grouping by similarity (Hunt and Halper, 2008) and possibly also by common fate (Wagemans et al., 2012) play crucial roles in biological motion perception. The current study demonstrated that the number of necessary elements for recognition of biological motion is relatively small, one again emphasising our high sensitivity to information on biological motion stimuli. Additionally, we hypothesise that another factor supporting sensitivity to motion information is the reaction to a coherent pattern representing a motion event; this seems to be plausible because normally motion and spatial perception in the visual field is connected with goal-oriented action in perceptual interpretation of stimuli (Johansson et al., 1980; Zacks et al., 2011).

In the current study we also determined, whether the number of dots sufficient for biological motion is similar in the central and peripheral visual field. The experimental setup of our study was similar to that used by Ikeda et al. (2005) and Gurnsey et al. (2008; 2010), meaning that the size of the point-light walkers and the chosen eccentricities for demonstrating the stimulus in near the periphery, were similar.

As expected, task performance deteriorated when the stimulus was presented eccentrically, but performance was improved by increasing the stimulus dimensions. Similarly to the results by Gurnsey et al. $(2008 ; 2010)$ our study showed that stimulus magnification indeed can compensate for the reduced performance in eccentric viewing, leading to similar results in central and peripheral visual fields. However, using a similar experimental setup where the participants had to discriminate between biological motion and its scrambled version, Ikeda et al. (2005) concluded that stimulus magnification cannot compensate for the reduced performance in periphery. We tend to agree with Thompson et al. (2007) that there might be differences in processes that provide figure-ground discrimination in central and peripheral visual fields, i.e. difficulties in segregation of the biological object from the surrounding visual noise (used by Ikeda et al. (2005), but not by Thompson et al. (2007)). Furthermore, these differences might apply not only to figure-ground discrimination, but also to other visual tasks (perceptual grouping, motion detection, etc.). Studies analysing figure-ground discrimination and the effects of crowding for patients with age-related macular degeneration (AMD) demonstrated that these patients performed worse than normally sighted subjects in tasks where they had to detect a target demonstrated either on white or related/unrelated background (Tran et al., 2011). Since the central vision for patients with AMD is often distorted and they have to rely on eccentric information perception, the reduced performance for these patients indeed can be related to different performance of figure-ground discrimination in central and peripheral visual fields, which is also crucial in global processes in biological motion perception.

We also have to bear in mind that all previously mentioned biological motion studies (including ours) in the peripheral visual field require that participants observe the stimuli binocularly. However, one needs to consider that the level of binocular summation declines toward the visual field periphery (Zlatkova et al., 2001), suggesting that binocular viewing of a centrally demonstrated stimuli can be more precise due to the neural summation of the visual information. Hence, in order to properly determine whether the central visual field is specialised for any visual information analysis (perceptual grouping, motion perception, face perception etc.), the task should be performed monocularly, by occluding one (usually the non-dominant) eye.

\section{CONCLUSIONS}

The current study explored the perception of biological motion in central and peripheral visual fields. The results indicate that the number of dots sufficient for biological motion perception is approximately $5(4.7 \pm 0.1)$. The significance of certain dots or combinations of dots might lead to better performance that using others. In the current study every task level was performed ten times. This not only improved measurement sensitivity (the standard deviation of results for each participant in the central visual field did not exceed 1 point), but also suggests that random combinations of dots can support such performance. Of course, the current study could be extended by analysing the significance of certain dots or combinations not only in tasks of specific information analysis (direction, gender etc.), but also in simple biological motion recognition. 
We observed that in the case of no visual noise, the perception of biological motion in the central visual field and near periphery can be similar in cases where stimuli are magnified. As demonstrated by Ikeda et al. (2005) and Tran et al. (2011), task performance in certain figure-ground discrimination tasks deteriorates towards the periphery. However, more studies are needed to generalise these conclusions. The next study that we have undertaken is to analyse the tasks of figure-ground discrimination not only for biological motion perception, but also for perceptual grouping and simple translation motion analysis when the stimuli are embedded in visual noise.

\section{REFERENCES}

Atkinson, A. P. (2009). Impaired recognition of emotions from body movements is associated with elevated motion coherence thresholds in autism spectrum disorders. Neuropsychologia, 47, 3023-3029.

Barclay, C. D., Cutting, J. E., Kozlowski, L. T. (1978). Temporal and spatial factors in gait perception that influence gender recognition. Percept. Psychophys., 23 (2), 145-152.

Barrett, H. C., Todd, O. M., Miller, G. F., Blythe, P. W. (2005). Accurate judgments of intention from motion cues alone: A cross-cultural study. Evol. Hum. Behav., 26 (4), 313-331.

Beintema, J. A., Lappe, M. (2002). Perception of biological motion without local image motion. Proc. Natl. Acad. Sci. USA, 99 (8), 5661-5663.

Bertenhal, B. I., Pinto, J. (1994). Global processing of biological motion. Psychol. Sci., 5 (4), 221-225.

Blake, R., Schiffrar, M. (2007). Perception of human motion. Annu. Rev. Psychol., 58, 47-73.

Boyton, G. M., Duncan, R. O. (2002). Visual acuity correlates with cortical magnification factors in human V1 [Abstract]. J. Vis., 2 (10), 11.

Campbell, R. A., Lasky, E. Z. (1968). Adaptive Threshold Procedures: BUDTIF. J. Acoust. Soc. Amer., 44 (2), 537-541

Chung, S. T. L., Mansfield, J. S., Legge, G. E. (1998). Psychophysics of reading. XVIII. The effect of print size on reading speed in normal peripheral vision. Vis. Res., 38 (19), 2949-2962.

Clarke, T. J., Bradshaw, M. F., Field, D. T., Hampson, S. E., Rose, D. (2005). The perception of emotion from body movement in point-light displays of interpersonal dialogue. Perception, 34, 1171-1180.

Cutting, J. E., Kozlowski, L. T. (1977). Recognizing friends by their walk: Gait perception without familiarity cues. Bull. Psychonomic Soc., 9 (5), 353-356.

Cutting, J. M., Moore, C., Morrison, R. (1988). Masking the motions of human gait. Percept. Psychophys., 44 (4), 339-347.

Duncan, R., O., Boynton, G., M. (2003). Cortical magnification within human primary visual cortex correlates with acuity thresholds. Neuron, $\mathbf{3 8}$, 659-667.

Finlay, D. (1982). Motion perception in the peripheral visual field. Perception, 11 (4), 457-462.

Freire, A., Lewis, T. L., Maurer, D., Blake, R. (2006). The development of sensitivity to biological motion in noise. Perception, 35, 647-657.

Giese, M. A. (2015). Biological and body motion perception In: Wagemans, J. (Ed.). The Oxford Handbook of Perceptual Organization. Oxford University Press, Oxford, pp. 575-600.

Giese, M. A., Lappe, M. (2002). Measurement of generalization fields for the recognition of biological motion. Vis. Res., 42 (15), 1847-1858.
Gurnsey, R., Roddy, G., Ouhnana, M., Troje, N. F. (2008). Stimulus magnification equates identification and discrimination of biological motion across the visual field. Vis. Res., 48, 2827-2834.

Gurnsey, R., Roddy, G., Troje, N. F. (2010) Limits of peripheral direction discrimination of point-light walkers. J. Vis., 10 (2), 1-17.

Higgins, K. E., Arditi, A., Knoblauch, K., (1996). Detection and identification of mirror-image letter pairs in central and peripheral vision. Vis. Res., 36 (2), 331-337.

Hunt, A. R. Halper, F. (2008). Disorganizing biological motion. J. Vis., 8 (12), 1-5.

Ikeda, H., Blake, R., Watanabe, K. (2005). Eccentric perception of biological motion is unscalably poor. Vis. Res., 45, 1935-1943.

Johansson, G. (1973), Visual perception of biological motion and a model for its analysis. Percept. Psychophys., 14, 201-211.

Johansson, G., Van Hofsten, C., Jansson, G. (1980). Event perception. Ann. Rev. Psychol., 31, 27-63.

Johnston, A., Wright, M., (1986). Matching velocity in central and peripheral vision. Vis. Res., 26, 1099-1109.

Kalloniatis, M., Luu, C. (2005). Visual Acuity. In: Kolb, H., Fernandez, E., Nelson, R. (eds.). Webvision: The Organization of the Retina and Visual System. Salt Lake City (UT): University of Utah Health Sciences Center. May 1 [Updated 2007 Jun 5]. Available from: http://www.ncbi.nlm.nih.gov/books/NBK11509/ (accessed 15 September 2016).

Kozlowski, L.T., Cutting, J. E. (1977). Recognising the sex of a walker from a dynamic point-light display. Percept. Psychophys., 21, 575-580

Lappin, J. S., Tadin, D., Nyquist, J. B., Corn, A. L. (2009). Spatial and temporal limits of motion perception across variations in speed, eccentricity, and low vision. J. Vis., 9 (1):30, 1-14.

Levitt, H. (1970). Transformed up-down methods in psychoacoustics. $J$. Acoust. Soc. Amer., 49 (2), 467-477.

Mather, G., Radford, K., West, S. (1992). Low level visual processing of biological motion. Proc. Roy. Soc. London B: Biol. Sci., 249, 149-155.

Mather, G., Murdoch, L. (1994). Gender discrimination in biological motion displays based on dynamic cues. Proc. Biol. Sci., 258 (1353), 273-279.

McKay, L., Mackie, J., Piggott, J., Simmons, D. R., Pollick, F. E. (2006). Biological motion processing in autistic spectrum conditions: Perceptual and social factors. J. Vis., 6, 1036.

McKee, S. P., Nakayama, K., (1984). The detection of motion in the peripheral visual field. Vis. Res., 24 (1), 25-32.

Meissirel, C., Wikler, K. C., Chalupa, L. M., Rakics, P., (1997). Early divergence of magnocellular and parvocellular functional subsystems in the embryonic primate visual system. Proc. Natl. Acad. Sci. USA, 94 (11), 5900-5905.

Nackaerts, E., Wagemans, J., Helsen, W., Swinnen, S. P., Wenderoth, N., Alaerts, K., (2012). Recognizing biological motion and emotions from point-light displays in autism spectrum disorders, PLOS ONE, 7 (9), e44473.

Neri, P., Concetta Morrone, M., Burr, D. C. (1998). Seeing biological motion. Nature, 395, 894-896.

Palmer, S. E. (1999). Vision Science: Photons to Phenomenology. MIT Press. 258 pp.

Rovamo, J., Virsu, V., Näsänen, R., (1978). Cortical magnification factor predicts the photopic contrast sensitivity of peripheral vision. Nature, 271, 54-56.

Sally, S. L., Gurnsey, R. (2003). Orientation discrimination in foveal and extra-foveal vision: Effects of stimulus bandwidth and contrast. Vis. Res., 43 (12), 1375-1385. 
Schouten, B., Davila, A., Verfaillie, K. (2013). Further explorations of the facing bias in biological motion perception: Perspective cues, observer sex, and response times. PloS One, 8 (2), e56978.

Sperling, G., Landy, M. S., Dosher, B. A., Perkins, M. E. (1989). Kinetic depth effect and identification of shape. J. Exper. Psychol.: Human Percept. Perform., 15 (4), 826-840.

Tannazzo, T., Kurylo, D. D., Bukhari, F. (2014). Perceptual grouping across eccentricity. Vis. Res., 103, 101-108.

Thompson, B., Hansen, B. C., Hess, R. F., Troje, N. F. (2007). Peripheral vision: Good for biological motion, bad for signal noise segregation? J. Vis., 7 (10):12, 1-7.

Tran, T. H., Guyader, N., Guerin, A., Despretz, P., Boucart, M., (2011). Figure ground discrimination in age-related macular degeneration. Investig. Ophthalm. Vis. Sci., 52, 1655-1660.

Troje, N. F., Westhoff, C. (2006). The inversion effect in biological motion perception: Evidence for a "Life Detector"? Curr. Biol., 16, 821-824.

Received 3 October 2016

Accepted in the final form 18 September 2017
Vanrie, J., Verfaillie, K. (2004). Perception of biological motion: A stimulus set of human point-light actions. Behav. Res. Meth. Instrum. Comp., 36, 625-629.

Wagemans, J., Elder, J. H., Kubovy, M., Palmer, S. E., Peterson, M. A., Singh, M., von der Heydt, R. (2012). A century of Gestalt psychology in visual perception: I. Perceptual grouping and figure-ground organization. Psychol. Bull., 138 (6), 1172-1217.

Wang, L., Yang, X., Shi, J., Jiang, Y. (2014). The feet have it: Local biological motion cues trigger reflexive attentional orienting in the brain. NeuroImage, 84, 217-224.

Wallach, H., O'Connell, D. N. (1953). The kinetic depth effect. J. Exper. Psychol., 45 (4), 205-217.

Wurbs, J., Mingolla, E., Yazdanbakhsh, A. (2013). Modeling a space-variant cortical representation for apparent motion. J. Vis., 13 (10):2, 1-17.

Zacks, J. M., Tversky, B., Iyer, G. (2001). Perceiving, remembering, and communicating structure in events. J. Exper. Psychol. Gen., 130 (1), $29-58$.

Zlatkova, M. B., Anderson, R. S., Ennis, F. A. (2001). Binocular summation for grating detection and resolution in foveal and peripheral vision. Vis. Res., 41 (24), 3093-3100.

\section{BIOLOG̣ISKĀS KUSTĪBAS UZTVERE CENTRĀLAJĀ REDZES LAUKĀ UN REDZES LAUKA PERIFĒRIJĀ}

Pētījumi, kas apskata bioloǵiskās kustības uztveri pie samazināta punktu skaita, norāda, ka bioloğiskās kustības stimulu iespējams uztvert pat tad, ja tiek demonstrēta tikai objekta apakšējā daḷa vai ja objektu veidojošo punktu skaits ir samazināts. Taču kāds ir minimālais punktu skaits, pie kura ir iespējams atšķirt bioloğisko kustību no tās jauktās versijas? Šajā pētījumā gūtie rezultāti norāda, ka bioloǵisko kustību ir iespējams atškirt no tās jauktās versijas, ja objekts tiek veidots no aptuveni $5(4,7 \pm 0,1)$ punktiem. Pētījumā tika apskatīts, vai slieksnis, kas raksturo minimālo punktu skaitu, pie kura iespējams izškirt bioloǵisko kustību, ir vienlīdz liels centrālajā redzes laukā un redzes lauka perifērijā. Gūtie rezultāti norāda, ka pietiekams stimulu palielinājums spēj nodrošināt vienlīdz labu sniegumu centrālajā redzes laukā un redzes lauka perifērijā. Traucēta bioloğiskās kustības uztvere, ko demonstrējuši citi pētījumi, nav saistāma ar globālās informācijas apstrādi bioloğiskās kustības uztverē. 